\title{
FAKTOR YANG BERHUBUNGAN DENGAN PELAKSANAAN GERAKAN KETUK PINTU DI PUSKESMAS ARCAMANIK
}

\author{
${ }^{1}$ Gita Komara, ${ }^{2}$ Asri Handayani Solihin, ${ }^{3}$ Yeni Suryamah \\ ${ }^{1}$ UPT Puskesmas Arcamanik Bandung, \\ gitakomara82@gmail.com \\ ${ }^{2}$ STIKes Dharma Husada Bandung, \\ asrihandayani@ stikesdhb.ac.id \\ ${ }^{3}$ STIKes Dharma Husada Bandung, \\ yeni_suryamah@hotmail.com
}

\begin{abstract}
Arcamanik Community Health Centre launched a program namely "gerakan ketuk pintu" by the cadres of Tuberculosis (TB) in a bid to improve the control of TB disease. Based on the upshot in March 2017 had no significant impact on the coverage due to several factors that can be conttributed such as the knowledge, attitude, motivation, and working period of TB cadres. Therefore, this research aimed to determine which factors that related to the implementation of the gerakan ketuk pintu in Arcamanik Health Centre Care through correlation descriptive type with cross-sectional approach. The sample is 31 people. In this research, Questionnaires and standard operating procedures (SOP) lists were used as an instrument. Data analysis using Chi Square Test. The results that factors related to the implementation of "gerakan ketuk pintu" is motivation $(p=0,005)$, attitude $(p=0,02)$, and knowledge $(p=0,031)$ and not correlated with working time period $(p=1,000)$. From this results, Arcamanik Community Health Centre are expected to aid the roles of cadres within the "gerakan ketuk pintu" through the health education and training periodically, conducting a counseling and budgetary planning to support the implemented program
\end{abstract}

Keywords:Active case finding, attitude, knowledge, motivation, working time periode.

\section{PENDAhUluaN}

TB Paru merupakan salah satu penyakit menular yang menjadi prioritas program kesehatan. Berdasarkan laporan WHO (2015) juga dipaparkan bahwa angka kasus TB baru yang ditemukan hanya $32 \%$ atau 324.000 kasus dari total 1.000 .000 kasus TB. Berdasarkan data tersebut berarti masih ada sekitar 676.000 atau 68\% kasus TB baru yang masih belum di temukan, diobati dan dilaporkan.

Hasil survey prevalensi TB yang dilakukan oleh Badan Litbangkes Kemenkes tahun 2013-2014, angka insiden TB adalah 399 per 100.000 penduduk, dan angka prevalensi TB sebesar 647 per 100.000 penduduk (WHO, 2015). Jika jumlah penduduk Indonesia berkisar 250 juta orang, maka diperkirakan ada sekitar 1 juta pasien TB baru dan ada sekitar 1.6 juta pasien TB setiap tahunnya. Sedangkan jumlah kematian karena TB 100.000 orang per tahun, atau 273 orang perhari (Kemenkes RI, 2017).

Berdasarkan profil kesehatan Indonesia (Pusdatin, 2015) data hasil cakupan penemuan kasus baru TB terkonfirmasi BTA di Jawa Barat mencapai $31,46 \%$, hal ini merupakan urutan tertinggi di Indonesia. Selama 3 tahun 
terakhir memiliki cakupan Case Notification rate (CNR) yang stagnan yakni pada tahun 2013 sampai dengan 2015 mencapai angaka yang sama yaitu 135 per 100.000 penduduk.

Berdasarkan laporan monitoring, evaluasi dan validasi data P2TB Dinas Kesehatan Provinsi Jawa Barat pada tahun 2015 dalam pencapaian CNR, Dinas Kesehatan Kota Bandung mencapai 281,6 per 100.000 penduduk, Angka keberhasilan pengobatan $66,58 \%$, menempati peringkat ke-21 dari 27 Kabupaten/Kota di Jawa Barat (Profil Dinkes Jawa Barat, 2015).

Berdasarkan laporan P2TB UPT Puskesmas Arcamanik tahun 2015 pencapaian CNR sebanyak 48 dan pada tahun 2016 mengalami penurunan menjadi 42. Sementara angka keberhasilan pengobatan pada tahun 2016 masih rendah yaitu 60\% dari target $85 \%$. Cakupan pencapaian CNR tahun 2017 sampai dengan bulan September hanya sebesar $40 \%$ dari target $90 \%$.

Dalam upaya penemuan kasus TB secara aktif masif, Kementrian Kesehatan mengembangkan kegiatan mobilisasi masyarakat yang fokus menggambarkan peran masyarakat dalam mendukung upaya penanggulangan TB secara aktif melalui gerakan ketuk pintu (Kemenkes RI, 2017).

Gerakan ketuk pintu adalah suatu kegiatan kunjungan rumah yang dilakukan oleh kader TB terlatih untuk memberikan informasi mengenai TB sekaligus melakukan skrining/penapisan gejala TB pada semua anggota keluarga yang ditemui saat itu (minimal 1 orang dewasa) dan jika dari hasil skrining/penapisan ditemukan gejala TB (1 gejala utama TB atau 3 gejala tambahan) maka akan diberikan surat rujukan untuk periksa dahak di Fasyankes terdekat (Kemenkes RI, 2017).

Faktor - faktor yang berhubungan dengan pelaksanaan gerakan ketuk pintu oleh kader TB adalah pengetahuan, sikap, motivasi, masa kerja, pelatihan, penghargaan dan desain pekerjaan.

Tujuan penelitian ini adalah unutk mengetahui faktor-faktor yang berhubungan dengan pelaksanaan gerakan ketuk pintu oleh kader meliputi tingkat motivasi, sikap, masa kerja dan tingkat pengetahuan, kader TB sehingga gerakan ketuk pintu oleh kader dapat berkontribusi bagi keberhasilan dalam pengendalian TB.

\section{METODE PENELITIAN}

Jenis penelitian yang digunakan adalah korelasional dengan pendekatan cross sectional. Variabel penelitian terdiri dari variable dependen yaitu motivasi, sikap, masa kerja dan pengetahuan Kader TB sedangkan variable independen yaitu gerakan ketuk pintu. Populasi pada penelitian ini adalah seluruh kader TB di UPT Puskesmas Arcamanik sebanyak 31 orang .Teknik pengambilan sampel dengan cara total sampling.

Instrumen dalam penelitian ini satu kuesioner yang meliputi motivasi, sikap, masa kerja dan pengetahuan Kader TB terkait gerakan ketuk pintu.Variabel pelaksanaan gerakan ketuk pintu oleh kader TB diperoleh dari hasil cheklist kegiatan kader berdasarkan 
daftar tilik standar operasional prosedur ketuk pintu. Setelah data terkumpul kemudian diolah dengan cara Editing, Coding, Tabulating dan Processing.

Analisis Univariat dilakukan untuk melihat distribusi frekuensi dan proporsi dari karakteristik faktor yang berhubungan dengan pelaksanaan gerakan ketuk pintu. Data hasil pengamatan dicatat dan diringkas dalam bentuk tabel distribusi frekuensi lalu dihitung proporsinya atau presentasinya dan disajikan dalam bentuk tabel. Analisa Bivarat dilakukan untuk mengidentifikasi hubungan variabel bebas dan variabel terikat. Analisa bivaruat yang digunakan adalah uji Chi Kuadrat $\left(\mathrm{X}^{2}\right)$.

\section{HASIL DAN PEMBAHASAN}

\section{Hasil Penelitian}

\section{a. Pelaksanaan Gerakan Ketuk Pintu}

Peneliti melakukan analisis deskriptif univariat dengan menggunakan skala ukur mean karena data terdistribusi normal melalui uji normalitas univariat skewness dimana nilai statistic dibagi standar defivasi adalah $<2$.

Tabel 1

Distribusi Frekuensi Gerakan Ketuk Pintu oleh Kader TB di Wilayah UPT Puskesmas Arcamanik

\begin{tabular}{lcc}
\hline $\begin{array}{c}\text { Variabel Gerakan } \\
\text { Ketuk Pintu }\end{array}$ & Frekuensi & $\%$ \\
\hline Baik & 11 & 35.5 \\
\hline Kurang Baik & 20 & 64.5 \\
\hline Total & 31 & 100 \\
\hline
\end{tabular}

Berdasarkan tabel 1 tentang gerakan ketuk pintu oleh responden di wilayah kerja UPT Puskesmas Arcamanik Kota Bandung menggambarkan bahwa dari 31 responden Jurnal Penelitian Kesehatan STIKes Dharma Husada Bandung sebanyak 20 responden (64,5\%) memiliki kinerja kurang baik artinya kader belum melakukan kegiatan ketuk pintu sesuai prosedur yang ditetapkan oleh puskesmas.

\section{b. Gambaran Motivasi, Sikap, Masa Kerja dan Pengetahuan Kader TB}

Tabel 2

Distribusi frekuensi faktor Motivasi, sikap, masa kerja dan pengetahuan Kader TB di wilayah kerja UPT Puskesmas Arcamanik

\begin{tabular}{lcc}
\hline \multicolumn{1}{c}{ Variabel } & Frekuensi & $\%$ \\
\hline Motivasi & & \\
\hline Baik & 21 & 67.7 \\
\hline Kurang baik & 10 & 32.3 \\
\hline Sikap & & \\
\hline Mendukung & 19 & 61.3 \\
\hline Kurang mendukung & 12 & 38.7 \\
\hline Masa Kerja & & \\
\hline Lama & 17 & 54.8 \\
\hline Baru & 14 & 45.2 \\
\hline Pengetahuan & & \\
\hline Baik & 14 & 45.2 \\
\hline Kurang Baik & 17 & 54.8 \\
\hline & 31 & 100 \\
\hline
\end{tabular}

Berdasarkan tabel 2 tentang motivasi responden di wilayah kerja UPT Puskesmas Arcamanik Kota Bandung tahun 2017 menggambarkan bahwa dari 31 responden sebanyak 21 responden $(67,7 \%)$ memiliki motivasi yang baik artinya sebagian besar kader memiliki tingkat upaya yang tinggi dalam pelaksanaan gerakan ketuk pintu program TB. Sikap kader di wilayah kerja UPT Puskesmas Arcamanik Kota Bandung tahun 2017 menggambarkan bahwa dari 31 responden sebanyak 19 responden $(61,3 \%)$ memiliki sikap yang mendukung artinya kader merespon dengan baik segala hal yang berhubungan dengan perasaan, dukungan dan 
hubungan yang signifikan antara masa kerja dengan gerakan ketuk pintu oleh kader TB di Wilayah kerja UPT Puskesmas Arcamanik pada tahun 2017.

Berdasarkan tabel 3 menunjukan bahwa dari 14 responden yang memiliki pengetahuan baik sebanyak 8 responden $(57,1 \%)$ melakukan kegiatan gerakan ketuk pintu dengan baik dan dari 17 responden yang memiliki pengetahuan kurang baik, 14 responden 82,4\%) melakukan kegiatan gerakan ketuk pintu dengan kurang baik . Dari hasil uji statistik fisher's exact di peroleh $(\mathrm{P}$-value $=0,031<0,05)$, menunjukan bahwa Ho ditolak, artinya ada hubungan yang signifikan antara pengetahuan dengan gerakan ketuk pintu oleh kader TB di Wilayah kerja UPT Puskesmas Arcamanik pada tahun 2017.

\section{Pembahasan}

\section{a. Gambaran Gerakan Ketuk Pintu Oleh Kader TB}

Berdasarkan analisis tentang gerakan ketuk pintu oleh kader TB di wilayah kerja UPT Puskesmas Arcamanik Kota Bandung tahun 2017 menggambarkan bahwa dari 31 responden sebanyak 20 responden $(64,5 \%)$ memiliki kinerja kurang baik artinya kader belum melakukan kegiatan ketuk pintu sesuai prosedur yang ditetapkan oleh puskesmas.

Dari daftar tilik didapatkan bahwa poin yang paling banyak tidak dilakukan adalah kader tidak memberikan edukasi kepada warga yang dikunjungi sesuai informasi pada leafleat TB, hal ini dikarenakan kader merasa kurang percaya diri dalam memberikan pemahaman dan informasi kepada masyarakat yang dikunjungi (sumber : hasil wawancara dengan beberapa responden).

Selain itu, poin yang banyak tidak dilakukan adalah tidak dilakukannya rujukan kasus terduga TB dan pengiriman laporan bulanan ketuk pintu. Setelah dilakukan wawancara kepada beberapa responden, didapatkan data bahwa kader merasa sibuk dengan banyaknya beban pelaporan yang tumpang tindih dikarenakan satu kader merangkap penanggungjawab berbagai program kesehatan. Satu orang kader merangkap sebagai kader TB, kader kesling, kader lansia dan lain-lain. Hal ini dikarenakan terbatasnya kuantitas dan kualitas kader sehingga belum semua kader melaporkan kegiatan ketuk pintu secara rutin ke puskesmas.

\section{b. Gambaran Motivasi, Sikap, Masa Kerja dan Pegetahuan Kader TB}

Berdasarkan hasil analisis tentang motivasi responden di wilayah kerja UPT Puskesmas Arcamanik Kota Bandung tahun 2017 menggambarkan bahwa dari 31 responden sebanyak 21 responden $(67,7 \%)$ memiliki motivasi yang baik artinya sebagian besar kader memiliki tingkat upaya yang tinggi dalam pelaksanaan gerakan ketuk pintu program TB.

Menurut teori Herzberg tahun 1950 dalam Notoatmodjo (2014), menyatakan bahwa faktor - faktor yang dapat meningkatkan atau memotivasi seseorang dalam meningkatkan kinerjanya adalah kelompok faktor - faktor motivasional yaitu prestasi, penghargaan, 
tanggung jawab, kesempatan untuk maju dan pekerjaan itu sendiri. Dalam penelitian Wahyudi (2010) mengatakan bahwa Motivasi merupakan faktor pendorong bagi seseorang untuk bertindak semakin kuat sehingga membuat seseorang semakin mudah untuk bergerak.

Kader TB melakukan tugas secara sukarela, secara umum memiliki motivasi dalam dirinya yaitu kepedulian akan kesehatan di masyarakat, sehingga tanpa memperoleh kompensasi kader tetap setia melakukan tugasnya. Penelitian Wahyudi (2010) dan penelitian Syafei (2010) memperoleh hasil banyak kader yang memiliki motivasi dengan kategori baik, tapi berbeda hasil dengan penelitian Nugroho (2008) yaitu lebih banyak kader yang memiliki motivasi yang kurang baik.

Dari kuesioner didapatkan data bahwa nilai terendah ada pada pertanyaan no. 10 dan no. 7, yaitu rata-rata responden merasa kesulitan dalam memberikan informasi dan pemahaman pada masyarakat tentang TB dan ketuk pintu, serta rata - rata responden menyatakan bahwa menjadi kader TB itu berat. Hal tersebut dapat mempengaruhi motivasi kader dalam gerakan ketuk pintu, sulitnya memberikan informasi dan pemahaman dapat menghambat motivasi kader sehingga program ketuk pintu tidak berjalan optimal, kader menjadi enggan melakukan kunjungan rumah atau melakukan kunjungan rumah tapi informasi tidak tersampaikan dengan baik. Sehingga pelaporan kegiatan ketuk pintu dapat berkurang bahkan bisa mengakibatkan tidak melaporkan sama sekali.

Data nilai terbesar ada pada pertanyaan no. 1 yaitu responden merasa bahwa gerakan ketuk pintu TB harus aktif dilakukan. Maka, meskipun beberapa kader ada yang merasa berat dalam melakukan tugasnya, tapi sebagian besar kader memiliki motivasi yang kuat untuk melakukan kegiatan ketuk pintu. Hal ini dikarenakan kader merasa bertanggungjawab untuk melaksanakannya dan sebagian besar tokoh masyarakat mendukung kegiatan ketuk pintu.

Hasil analisis sikap kader TB di wilayah kerja UPT Puskesmas Arcamanik Kota Bandung tahun 2017 menggambarkan bahwa dari 31 responden sebanyak 19 responden $(61,3 \%)$ memiliki sikap yang mendukung artinya kader merespon dengan baik segala hal yang berhubungan dengan perasaan, dukungan dan suasana hati kader terhadap kegiatan gerakan ketuk pintu.

Sikap adalah reaksi atau respon seseorang yang masih tertutup terhadap suatu objek (wahyudi, 2010). Menurut Allport (1954) dalam Notoatmodjo (2010), sikap mempunyai 3 (tiga) komponen pokok, yaitu: Kepercayaan (keyakinan), ide dan konsep terhadap suatu objek; (2) Kehidupan emosional atau evaluasi emosional terhadap suatu objek; (3) Kecenderungan untuk bertindak (trend to behave).

Dari data didapatkan bahwa nilai terendah ada pada pertanyaan no. 4 yaitu sebagian besar responden merasa terbebani sebagai Kader TB dalam melaksanakan tugas terutama dalam 
kegiatan Gerakan Ketuk Pintu. Hal ini dapat menjadi hambatan dalam mendukung kegiatan ketuk pintu. Berdasarkan hasil wawancara, bahwa sebagian besar responden merasa terbebani karena merasa kurangnya wawasan yang mereka miliki sehingga sebagian besar responden menyatakan perlu meningkatkan pengetahuan tentang program TB. Dengan adanya peningkatan pengetahuan diharapkan kader akan cepat tanggap dan pro aktif dalam menyikapi kegiatan ketuk pintu. Meskipun demikian, sebagian besar responden memiliki keyakinan bahwa penyakit TB merupakan penyakit infeksi menular yang harus segera diketahui dan ditangani bersama serta dirujuk secepatnya ke Puskesmas dengan tatalaksana penanganan TB sesuai standar. Dengan adanya keyakinan dan pemahaman tersebut maka sebagian besar responden menyatakan mendukung kegiatan ketuk pintu.

Berdasarkan analisis tentang masa kerja responden di wilayah kerja UPT Puskesmas Arcamanik Kota Bandung tahun 2017 menggambarkan bahwa dari 31 responden sebanyak 17 responden (54,8\%) memiliki masa kerja $\geq 5$ tahun sebagai Kader TB.

Masa kerja berhubungan dengan waktu kerja seseorang, yaitu segi kuantitas seseorang didalam menjalani pekerjaannya (Sumartini, 2014). Sejalan dengan masa kerja yang bertambah, seseorang diharapkan semakin berkembang dan menguasai pekerjaannya dengan lebih baik serta dapat mengatasi berbagai macam persoalan yang berkaitan dengan tugasnya.
Banyaknya kader dengan masa kerja $\geq 5$ tahun dikarenakan minimnya regenerasi kader, tidak mudah mendapatkan warga masyarakat yang mau bekerja secara sukarela menjadi kader. Kader dipilih oleh RW setempat dan di SK kan oleh kelurahan dengan masa kerja yang tidak terbatas. Banyaknya jumlah kader dengan masa kerja $\geq 5$ tahun mengakibatkan sebagian besar kader berusia tua (46-65 tahun) yaitu sebanyak 67,7\% dari total kader TB. Usia tua berdampak pada penurunan daya ingat dan fungsi fisik, misalnya mudah lelah sehingga berdampak pada penurunan produktifitas. Ditambah lagi banyaknya kader dengan kerja rangkap dapat menambah menurunnya produktifitas kinerja kader.

Tapi, banyaknya kader dengan masa kerja $\geq 5$ tahun dapat berdampak positif dalam memudahkan koordinasi dengan petugas kesehatan, tokoh masyarakat dan masyarakat secara umum, karena hubungan sudah terjalin dengan baik dan cukup lama.

Gambaran hasil analisis tentang pengetahuan responden di wilayah kerja UPT Puskesmas Arcamanik Kota Bandung tahun 2017 bahwa dari 31 responden sebanyak 17 responden $(54,8 \%)$ memiliki pengetahuan yang kurang baik mengenai penyakit TB dan gerakan ketuk pintu.

Menurut Notoatmodjo

(2010), pengetahuan mencakup 6 tingkat dan untuk kader TB ini berdasarkan hasil telah berada pada tingkat yang keenam yaitu evaluasi, dimana kader telah mampu mengaplikasikan hal yang diketahuinya dan telah mampu membuat penilaian seperti menentukan 
kemungkinan terduga TB dan merujuknya ke Puskesmas. Hasil penelitian yang menunjukkan bahwa terdapat lebih banyak kader memiliki pengetahuan baik dibandingkan dengan yang kurang baik yang dilakukan oleh wahyudi (2010) dan juga penelitian oleh Syafei (2010), tetapi berbeda dengan Sandiyani (2011) dan Nugroho (2008) yang memperoleh hasil yaitu lebih banyak kader yang berpengetahuan kurang baik.

Dari data didapatkan bahwa masih banyaknya kader yang belum paham tentang kegiatan ketuk pintu, terbukti banyak responden yang salah dalam menjawab pertanyaan no. 6 - 10. Tingginya usia diatas 45 tahun dapat mengakibatkan rendahnya daya ingat kader serta adanya tingkat pendidikan kader setingkat SD $(6,5 \%)$ dapat berpengaruh terhadap rendahnya pemahaman kader.

Berdasarkan hasil wawancara dengan beberapa responden, dikatakan bahwa pelatihan kader TB yang telah dilaksanakan masih terlalu singkat dan tidak ada pertemuan lanjutan secara khusus yang berkesinambungan untuk meningkatkan pengetahuan kader. Beberapa responden berharap akan ada pertemuan atau pembinaan berkesinambungan untuk memperkaya informasi, wawasan dan pemahaman tentang TB dan ketuk pintu.

\section{c. Hubungan motivasi, sikap, masa kerja dan pengetahuan kader dengan gerakan ketuk pintu oleh kader TB}

Hasil analisis menunjukan bahwa dari 21 responden yang memiliki motivasi baik sebanyak 11 responden $(52,4 \%)$ melakukan Jurnal Penelitian Kesehatan STIKes Dharma Husada Bandung kegiatan gerakan ketuk pintu dengan baik dan dari 10 responden yang memiliki motivasi kurang baik, $100 \%$ responden melakukan kegiatan gerakan ketuk pintu dengan kurang baik . Dari hasil uji statistik fisher's exact di peroleh P-value $=0,005$ dengan $\alpha=0,05$, maka p-value $<\alpha$ menunjukan bahwa H0 ditolak, artinya ada hubungan yang signifikan antara motivasi dengan gerakan ketuk pintu oleh kader TB di Wilayah kerja UPT Puskesmas Arcamanik pada tahun 2017.

Adanya hubungan antara motivasi kader dengan gerakan ketuk pintu oleh kader TB berarti semakin tinggi motivasi kader maka semakin baik pula kegiatan gerakan ketuk pintu yang dilakukan oleh kader. Motivasi merupakan faktor pendorong bagi seseorang untuk bertindak, semakin kuat dorongan yang dimiliki maka semakin mudah seseorang untuk bergerak.

Kader kesehatan merupakan sasaran yang tepat dalam pelaksanaan gerakan ketuk pintu karena dianggap sebagai tempat rujukan pertama pelayanan kesehatan. Kader ini adalah kepanjangan tangan dari puskesmas kepada masyarakat di wilayah kerjanya. Kader dianggap sebagai rujukan dalam penanganan berbagai masalah kesehatan termasuk TB. Dengan memiliki motivasi yang tinggi dalam melaksanakan gerakan ketuk pintu maka upaya pelaksanaan kegiatan akan dapat berjalan dengan baik, sesuai dengan hasil penelitian yang telah dilakukan bahwa motivasi kader memiliki hubungan yang signifikan terhadap pelaksanaan gerakan ketuk pintu oleh kader TB. 
Penelitian yang dilakukan oleh wahyudi (2010) menyatakan bahwa terdapat hubungan yang positif dan signifikan antara motivasi kader dengan penemuan suspek TB Paru di Puskesmas. Begitu juga dengan penelitian Wijaya, I. M. K (2013) menunjukkan bahwa terdapat hubungan signifikan antara motivasi dengan keaktifan kader. Kader kesehatan dengan motivasi tinggi memiliki kemungkinan untuk aktif 15 kali lebih besar daripada motivasi rendah.

Tingginya motivasi kader ini diantaranya karena aktifnya dukungan tokoh masyarakat setempat sehingga turut memudahkan pelaksanaan kegiatan terutama dalam perizinan dan membantu sosialisasi akan adanya kader yang datang berkunjung kerumah-rumah untuk deteksi kasus TB. Selain itu, tingginya motivasi internal dari kader dengan adanya rasa tanggungjawab yang besar akan mempermudah terlaksananua kegiatan ketuk pintu.

Motivasi yang tinggi juga tidak lepas dari adanya komunikasi efektif antara kader dengan petugas kesehatan yaitu adanya pemanfaatan teknologi dalam menjalin komunikasi melalui grup whatsapp yang menjadi sarana petugas dalam membantu meningkatan motivasi eksternal, misalnya dengan memberikan feedback hasil laporan kader, mengingatkan tata cara pelaporan dan tanya jawab seputar program TB.

Untuk peningkatan motivasi kader dalam pelaksanaan ketuk pintu harus didukung pula dengan peningkatan kemampuan kader dalam memberikan edukasi tentang ketuk pintu dan penyakit TB kepada masyarakat. Sehingga kegiatan ketuk pintu dapat dilaksanakan oleh kader secara optimal tanpa merasa terbebani atau terpaksa.

Penghargaan dapat pula diberikan dalam upaya peningkatan motivasi kader dalam gerakan ketuk pintu, penghargaan dapat diberikan baik dalam bentuk moril atau materil.

Berdasarkan hasil analisis menunjukan bahwa dari 19 responden yang memiliki sikap yang mendukung sebanyak 10 responden $(52,6 \%)$ melakukan kegiatan gerakan ketuk pintu dengan baik dan dari 12 responden yang memiliki sikap kurang mendukung, 11 responden $(91,7 \%)$ melakukan kegiatan gerakan ketuk pintu dengan kurang baik . Dari hasil uji statistik fisher's exact di peroleh (Pvalue $=0,02<0,05)$, menunjukan bahwa $\mathrm{H} 0$ ditolak dan Ha diterima artinya ada hubungan yang signifikan antara sikap dengan gerakan ketuk pintu oleh kader TB di Wilayah kerja UPT Puskesmas Arcamanik pada tahun 2017.

Sikap merupakan indikasi kemauan untuk bertindak, semakin baik sikap yang ditunjukkan oleh kader maka kemauan kader TB untuk melaksanakan gerakan ketuk pintu semakin baik pula. Sikap kader kesehatan merupakan domain yang sangat penting sebagai dasar kader kesehatan dalam melakukan keaktifannya dalam pengendalian kasus tuberkulosis. Faktor-faktor yang mempengaruhi perilaku seseorang salah satunya adalah sikap dari orang tersebut (Basri, et. al, 2009).

Hasil penelitian wahyudi (2010) bahwa 
terdapat hubungan hubungan yang positif dan signifikan antara sikap kader dengan penemuan suspek TB Paru di Puskesmas. Penelitian Wijaya, I. M. K. (2013) menyatakan adanya hubungan yang signifikan antara sikap dengan keaktifan kader, kader kesehatan dengan sikap baik memiliki kemungkinan untuk aktif 8 kali lebih besar daripada sikap kurang.

Banyaknya sikap kader yang mendukung pelaksanaan kegiatan ketuk pintu merupakan langkah penting dalam keberhasilan program, tingginya keyakinan kader tentang tugas dan tanggungjawab serta pemahaman yang baik tentang resiko penularan $\mathrm{TB}$ dapat menjadi faktor penting dalam upaya mendukung pelaksanaan kegiatan ketuk pintu. Sikap yang mendukung ini perlu ditunjang dengan tingginya rasa percaya diri kader melalui upaya peningkatan kapasitas sehingga kader tidak merasa terbebani dalam melaksanakan tugasnya tetapi merasa menjadi kebutuhan dalam mewujudkan masyarakat bebas TB.

Hasil penelitian menunjukan bahwa dari 17 responden yang memiliki masa kerja lama ( $\geq 5$ tahun) sebanyak 11 responden $(64,7 \%$ ) melakukan kegiatan gerakan ketuk pintu dengan kurang baik dan dari 14 responden yang memiliki masa kerja baru ( $<5$ tahun), 9 responden $(64,3 \%)$ melakukan kegiatan gerakan ketuk pintu dengan kurang baik . Dari hasil uji statistik fisher's exact test di peroleh $(\mathrm{P}$-value $=1,000>0,05)$, menunjukan bahwa H0 diterima, artinya tidak ada hubungan yang signifikan antara masa kerja dengan gerakan ketuk pintu oleh kader TB di Wilayah kerja
UPT Puskesmas Arcamanik pada tahun 2017.

Masa kerja kader dipandang berpengaruh terhadap kualitas kerja kader, karena dengan masa kerja yang lebih lama kader akan lebih banyak memiliki pengalaman dan keterampilan yang lebih baik dalam menyelesaikan tugasnya. Masa kerja Kader TB adalah lamanya seseorang menjadi Kader TB. Masa kerja diukur dengan satuan waktu, misalnya tahun atau bulan. Masa kerja berhubungan dengan waktu kerja seseorang, yaitu segi kuantitas seseorang didalam menjalani pekerjaannya (Sumartini, 2014).

Menurut hasil penelitian Sumartini (2014) terdapat hubungan antara karakteristik masa kerja dengan peran kader kesehatan dalam penemuan kasus TB di Kota Mataram. Masa kerja yang lebih lama memungkinkan pengalaman dan keterampilan dalam menjalankan peran yang lebih banyak sehingga dapat menjamin produktifitas kerja.

Akan tetapi hasil penelitian Fitriantoro (2009) menyatakan tidak ada hubungan signifikan antara masa kerja dengan kinerja. Hal ini dikarenakan semakin lama masa kerja maka semakin bertambah pula usia. Sedangkan untuk belajar/meningkatkan pengetahuan ada kecenderungan enggan dilakukan mengingat kecenderungan usia juga semakin tua. Faktorfaktor seperti kesehatan, daya tahan tubuh dan daya tangkap juga akan semakin menurun. Penelitian Sandiyani, R. A., \& Sandiyani, R. A (2011) menunjukkan bahwa tidak ada hubungan antara lama menjadi kader dan frekuensi pelatihan dengan perilaku penyampaian informasi tentang PUGS. 
Dari beberapa penelitian diatas dapat disimpulkan bahwa masa kerja tidak akan berperan besar dalam pelaksanaan gerakan ketuk pintu, hal ini diduga karena semakin lama menjadi kader TB belum tentu dapat melaksanakan kegiatan ketuk pintu dengan baik dikarenakan kegiatan ini masih baru dan belum dilaksanakan di wilayah lain secara berkesinambungan sehingga kader masih beradaptasi dengan kegiatan tersebut. Selain itu, lama menjadi kader harus didukung dengan sarana dan prasarana serta komunikasi yang berkesinambungan agar kegiatan dapat berjalan lancar, seperti lembar pelaporan, media KIE yang digunakan untuk kegiatan edukasi dan pemantauan secara terus menerus oleh petugas TB puskesmas. Hasil pengamatan menunjukkan bahwa sarana prasarana yang ada hanya laporan kegiatan untuk satu bulan dan media KIE yang terbatas. Sehingga banyak kader yang keberatan untuk memperbanyak sendiri.

Selain itu, banyaknya kader dengan masa kerja $\geq 5$ tahun yang mengakibatkan banyaknya usia tua ( $>46$ tahun) serta masih adanya kader dengan pendidikan SD sehingga berdampak terhadap rendahnya daya tangkap dan pemahaman. Maka, banyaknya masa kerja kader yang lama tidak berpengaruh secara signifikan terhadap keberhasilan pelaksanaan ketuk pintu.

Hasil penelitian menunjukan bahwa dari 14 responden yang memiliki pengetahuan baik sebanyak 8 responden $(57,1 \%)$ melakukan kegiatan gerakan ketuk pintu dengan baik dan dari 17 responden yang memiliki pengetahuan kurang baik, 14 responden 82,4\%) melakukan kegiatan gerakan ketuk pintu dengan kurang baik . Dari hasil uji statistik fisher's exact di peroleh $(\mathrm{P}-\mathrm{value}=0,031<0,05)$, menunjukan bahwa Ho ditolak, artinya ada hubungan yang signifikan antara pengetahuan dengan gerakan ketuk pintu oleh kader TB di Wilayah kerja UPT Puskesmas Arcamanik pada tahun 2017. Temuan pada penelitian ini sesuai dengan tinjauan teoritik.

Pengetahuan adalah hasil penginderaan manuasia, atau hasil tahu seseorang terhadap objek melalui indera yang dimilikinya (mata, hidung, telinga, dan sebagainya). Sebagian besar pengetahuan seseorang diperoleh melalui indera pendengaran (telinga), dan indera penglihatan (mata) (wahyudi, 2010).

Pengetahuan kader TB merupakan domain yang sangat penting sebagai dasar kader TB dalam melakukan keaktifannya dalam pelaksanaan gerakan ketuk pintu. Faktor-faktor yang mempengaruhi perilaku seseorang salah satunya adalah pengetahuan dari orang tersebut.

Menurut Wijaya, I. M. K (2013) bahwa terdapat hubungan yang secara statistik signifikan antara pengetahuan dengan keaktifan kader kesehatan, dimana pengetahuan tinggi memiliki kemungkinan untuk aktif dalam pengendalian kasus tuberkulosis 18 kali lebih besar dari pada pengetahuan rendah. Hasil penelitian lain yang sejalan adalah Wahyudi (2010) menyatakan bahwa terdapat hubungan yang positif dan signifikan antara pengetahuan dengan penemuan suspek TB Paru di Puskesmas 
Sanankulon .

Menurut beberapa responden, pelatihan kader TB yang sudah dilaksanakan terlalu singkat, tidak adanya pertemuan khusus yang berkesinambungan dalam upaya memperkaya informasi, wawasan dan koordinasi program TB. Informasi hanya disampaikan melalui pertemuan - pertemuan umum dan lewat media komunikasi (Handphone). Selain itu, ketuk pintu merupakan program baru sehingga masih banyak kader yang belum paham tatalaksananya.

Kurang baiknya pengetahuan kader berakibat pada kurangnya informasi yang disampaikan kepada masyarakat serta rendahnya partisipasi kader dalam pelaporan dan rujukan kasus TB ke puskesmas. Oleh karena itu, hanya sebagian kecil $(35,5 \%)$ kader yang melakukan kegiatan ketuk pintu dengan baik.

\section{SIMPULAN DAN SARAN}

\section{Simpulan}

Berdasarkan hasil penelitian dan pembahasan mengenai faktor - faktor yang berhubungan dengan pelaksanaan gerakan ketuk pintu oleh kader TB di UPT Puskesmas Arcamanik Kota Bandung tahun 2017, maka didapatkan kesimpulan sebagai berikut :

1. Berdasarkan hasil analisis responden di wilayah kerja UPT Puskesmas Arcamanik Kota Bandung tahun 2017 menggambarkan bahwa 64,5\% memiliki kinerja kurang baik dalam pelaksanaan gerakan ketuk pintu, $67,7 \%$ memiliki motivasi yang baik, $61,3 \%$ memiliki sikap yang mendukung, 54,8\% memiliki masa kerja $\geq 5$ tahun sebagai Kader TB dan 54,8\% memiliki pengetahuan yang kurang baik mengenai penyakit TB dan gerakan ketuk pintu.

2. Faktor - faktor yang berhubungan dengan gerakan ketuk pintu oleh kader TB di Wilayah kerja UPT Puskesmas Arcamanik pada tahun 2017 adalah motivasi (Pvalue $=0,005)$, sikap $(\mathrm{P}$-value $=0,02)$ dan pengetahuan $(\mathrm{P}$-value $=0,031)$. Tidak ada hubungan antara masa kerja dengan gerakan ketuk pintu oleh kader TB di Wilayah kerja UPT Puskesmas Arcamanik pada tahun $2017(\mathrm{P}$-value $=1,000>0,05)$.

\section{Saran}

1. Bagi Dinas Kesehatan

Bagi Dinas Kesehatan selaku pembuat kebijakan program pemberantasan penyakit TB, diharapkan dapat meningkatkan dukungan dalam upaya melibatkan peran serta kader untuk meningkatkan cakupan kegiatan program TB baik itu dukungan berupa sarana KIE, pelatihan dan dana.

2. Bagi UPT Puskesmas Arcamanik UPT Puskesmas Arcamanik agar dapat meningkatkan peran aktif kader dalam upaya pelaksanaan gerakan ketuk pintu disertai upaya peningkatan pengetahuan dan motivasi dalam bentuk pendidikan kesehatan atau pelatihan secara berkala, melakukan pendampingan dalam pelaksanaannya dan merencanakan anggaran yang cukup dalam upaya mendukung sarana yang diperlukan. 


\section{Bagi Kader TB}

Kader berupaya meningkatkan wawasan terkait TB dan ketuk pintu dengan banyak membaca atau bertanya kepada petugas kesehatan, memberikan usulan yang produktif kepada petugas puskesmas serta menjalin kolaborasi dengan tokoh masyarakat agar memberikan dukungan untuk meningkatkan pelaksanaan gerakan ketuk pintu.

\section{REFERENSI}

Basri C, Bergström K, Walton W, SuryaA, Voskens J and Metha F. 2009. Sustainable scaling up of good quality health worker education for tuberculosis control in Indonesia: a case study. Human Resources for Health, 7(85)

Fitriantoro. 2009. Hubungan Antara Usia dan Masa Kerja Dengan Kinerja Dosen. Universitas Sanata Darma, Yogyakarta.

Jabar DKP. 2015. Profil Kesehatan Jawa Barat 2014. Bandung: Dinas Kesehatan Provinsi Jawa Barat.

Kementrian Kesehatan Republik Indonesia. 2017. Petunjuk Teknis Tentang Ketuk Pintu Dalam Rangka Hari TB Sedunia. Jakarta: Kemenkes RI

Monitoring dan Evaluasi (Monev) Program TB; P2P Dinas Kesehatan Kota Bandung. 2016.

Notoatmodjo S. 2010. Metodologi Penelitian Kesehatan. Jakarta: Rineka Cipta

Notoatmojo S. 2014. Ilmu Prilaku Kesehatan. Jakarta : Rineka Cipta

Pusdatin. 2015. Profil Kesehatan Indonesia tahun 2015. Jakarta : Kemenkes RI

Sandiyani, R. A., \& Sandiyani, R. A. 2011. Lama Menjadi Kader, Frekuensi Pelatihan, Pengetahuan Gizi, Dan Sikap Kader Posyandu Dengan Perilaku Penyampaian Informasi Tentang Pesan Gizi Seimbang (Doctoral dissertation, Diponegoro University).

Sugiyono. 2012. Metode Penelitian Kuantitatif Kualitatif Dan $R \& D$. Bandung : Alfabeta
Sumartini, N.P. 2014. Penguatan Peran Kader Kesehatan Dalam Penemuan Kasus Tuberkulosis (Tb) Bta Positif Melalui Edukasi Dengan Pendekatan Theory of Planned Behaviour (Tpb).

Syafei, A. 2010. Faktor-Faktor yang Berhubungan dengan Partisipasi Kader dalam Kegiatan Gizi di Posyandu di Kelurahan Rengas Kecamatan Ciputat Timur Kota Tangerang Selatan. Universitas Islam Negeri Syarif Hidayatullah Jakarta.

WHO. 2016. Global Tuberculosis Report 2016. Geneva, Switzerland: Wolrd Health Organization.

Wahyudi. 2010. Hubungan Pengetahuan, Sikap Dan Motivasi Kader Dengan Penemuan Suspek Tuberkulosis Paru Di Puskesmas Sanankulon. Surakarta: Program Pascasarjana Universitas Sebelas Maret.

Wijaya, I. M. K. 2013. Pengetahuan, sikap dan motivasi terhadap keaktifan kader Dalam pengendalian tuberkulosis. Jurnal Kesehatan Masyarakat, 8(2). 